Tringali, A., and R. Bowman. 2015. Suburban immigrants to wildlands disrupt honest signaling in ultra-violet plumage. Avian Conservation and Ecology 10(1): 9. http://dx.doi.org/10.5751/ACE-00746-100109

Copyright (C) 2015 by the author(s). Published here under license by the Resilience Alliance.

Research Paper

\title{
Suburban immigrants to wildlands disrupt honest signaling in ultra- violet plumage
}

\author{
Angela Tringali ${ }^{1}$ and Reed Bowman ${ }^{1}$ \\ ${ }^{1}$ Avian Ecology Laboratory, Archbold Biological Station
}

\begin{abstract}
Urbanization changes habitat in a multitude of ways, including altering food availability. Access to human-provided food can change the relationship between body condition and honest advertisements of fitness, which may result in changes to behavior, demography, and metapopulation dynamics. We compared plumage color, its relationship with body condition and feather growth, and use as signal of dominance between a suburban and a wildland population of Florida Scrub-Jay (Aphelocoma coerulescens). Although plumage color was not related to body condition at either site, suburban birds had plumage with a greater proportion of total reflectance in the ultra-violet (UV) and peak reflectance at shorter wavelengths. Despite the use of plumage reflectance as a signal of dominance among individuals in the wildlands, we found no evidence of status signaling at the suburban site. However, birds emigrating from the suburban site to the wildland site tended to be more successful at acquiring breeder status but less successful at reproducing than were immigrants from an adjacent wildland site, suggesting that signaled and realized quality differ. These differences in signaling content among populations could have demographic effects at metapopulation scales and may represent an evolutionary trap whereby suburban immigrants are preferred as mates even though their reproductive success relative to effort is lower.
\end{abstract}

\section{Les oiseaux qui immigrent du milieu périurbain au milieu naturel perturbent le signalement honnête du plumage dans l'ultraviolet}

RÉSUMÉ. L'urbanisation affecte l'habitat d'une multitude de façons, entre autres en modifiant la disponibilité de la nourriture. L'accessibilité à la nourriture offerte par les humains peut intervenir dans la relation établie entre la condition physique et le signalement honnête de l'aptitude phénotypique, qui pourrait entrainer des changements dans le comportement, la démographie et la dynamique de métapopulations. Nous avons comparé la couleur du plumage, sa relation avec la condition physique et la croissance des plumes, et son utilisation pour signaler sa dominance dans une population occupant le milieu périurbain et une population occupant le milieu naturel chez le Geai à gorge blanche (Aphelocoma coerulescens). Même si la coloration du plumage n'était pas liée à la condition physique à aucun des deux sites, les oiseaux périurbains présentaient un plumage comportant une plus grande proportion de réflectance totale dans les ultraviolets (UV) et une réflectance maximale dans les longueurs d'ondes plus courtes, comparativement aux oiseaux du milieu naturel. Bien que les individus du milieu naturel utilisent la réflectance de leur plumage pour signaler leur dominance, nous n'avons pas observé ce comportement chez les individus périurbains. Toutefois, les oiseaux qui immigraient du site périurbain au site naturel avaient tendance à s'apparier avec plus de succès, mais à se reproduire avec moins de succès que les oiseaux qui immigraient d'un site naturel adjacent, ce qui laisse supposer que l'aptitude signalée diffère de l'aptitude réelle. Ces différences de signalement de l'aptitude parmi les populations pourraient avoir des effets démographiques à l'échelle des métapopulations et pourraient représenter un piège évolutif dans lequel les oiseaux qui immigrent du milieu périurbain sont préférés comme partenaires malgré que leur succès reproducteur relatif à l'effort soit plus faible.

Key Words: condition dependence; dispersal; honest advertisement; metapopulation; plumage; reproductive effort; signaling; suburban

\section{INTRODUCTION}

Urbanization is one of most ubiquitous ways humans modify the environment; more than one-half of the human population lives in urban areas, and these areas are expected to absorb the majority of the growing population (United Nations 2012). Urbanization fragments and degrades habitat and alters disturbance regimes, predator communities, and food availability, all of which affect how animals perceive their environment (Van Dyck 2012). An animal's perception of its environment can influence foraging (Brown and Kotler 2004), social interactions (Wong 2012), and dispersal and habitat selection (Pasinelli and Walters 2002, Schlaepfer et al. 2002). Additionally, environmental changes also may change how individual animals are perceived by conspecifics. Combined, these changes can alter demographic rates and subsequently population trends in and around urbanized areas.

The distribution, types, and availability of food are altered by urbanization (Chace and Walsh 2006). In addition to changing how animals perceive their environment, altered food availability can change how animals perceive one another. In animal communication, ornamental traits are generally considered honest advertisements of fitness. These signals may be honest because they are dependent on body condition (Kodric-Brown and Brown 1984) or are costly to maintain (Zahavi 1975, Grafen 1990). Human-provided foods are often abundant and 
ubiquitous, and the introduction of these anthropogenic sources of food can weaken the relationship between plumage coloration and body condition, degrading the advertisement's honesty and creating evolutionary traps whereby once adaptive behaviors become maladaptive (Rodewald et al. 2011). For example, in Northern Cardinal (Cardinalis cardinalis), the relationship between plumage brightness and body condition is weaker in suburban areas than in wildlands (Jones et al. 2010). Assessing other individuals, whether as potential mates or competitors, is adaptive (Johnstone 1995). If ornamentation no longer accurately reflects individual quality, but is still used to evaluate conspecifics, receivers of this signal may suffer a fitness cost. The potential breakdown of signaling and the associated demographic consequences is an underexplored consequence of urbanization.

We examined the effects of anthropogenic foods on body condition, plumage coloration, and dominance signaling by comparing a wildland and a suburban population of Florida Scrub-Jays (Aphelocoma coerulescens). In this species, plumage color is related to condition (Siefferman et al. 2008) and signals dominance among juveniles (Tringali and Bowman 2012). Whether this plumage also signals dominance in adults is unknown. We predicted that the lack of appropriate foods during the nestling phase, when the majority of body growth occurs, and abundance of foods during the fledgling phase, when the majority of feather growth occurs, would create a mismatch between body and plumage condition in suburban birds. If this mismatch exists and plumage color is less related to body condition in the suburbs, we predicted that suburban birds would not use plumage reflectance as a dominance signal. Additionally, if a mismatch between signaled quality (plumage reflectance) and actual quality exists, suburban birds dispersing to the wildlands should be more successful at obtaining breeding positions but less successful at producing offspring compared to those dispersing from wildland sites.

\section{METHODS}

\section{Study species}

The Florida Scrub-Jay is a cooperatively breeding habitat specialist. Individuals often delay dispersal, remaining in their natal territory where they participate in territorial defense, sentineling, and feeding young (Woolfenden and Fitzpatrick 1984, Hailman et al. 1994). Males and females usually pair in their second year (47\% for males and 58\% for females; Woolfenden and Fitzpatrick 1984). Dispersal distances are short; dispersals of one territory length are most common, and distances more than five territory lengths are rare (Woolfenden and Fitzpatrick 1984). These short dispersal distances, combined with habitat specificity and nonhabitat gaps separating habitat patches, reduce the possibility of birds dispersing and breeding outside of our study areas (Coulon et al. 2012). However, we conduct annual postbreeding season surveys off-site to document dispersal and breeding outside of the study area.

The Florida Scrub-Jay is Federally Threatened and endemic to Florida, USA. As of 1992-1993, approximately $30 \%$ of the extant population lived in suburban areas (Fitzpatrick et al. 1994). The Florida Scrub-Jay quickly acclimates to human presence. It frequents bird feeders, and some individuals are bold enough to take food directly from people's hands. This affability endears them to the residents of suburban neighborhoods, who readily provide them with peanuts and other foods. As a result, humanprovided foods, most of which are plant foods such as peanuts, bird seed, and bread, make up a large portion of the adult diet of suburban scrub-jays (Fleischer et al. 2003), as well as a significant component of the nestling diet (Sauter et al. 2006). In wildland habitat, nestlings are fed exclusively arthropods (Stallcup and Woolfenden 1978). Even though human-provided foods are not high quality for nestlings, parents may choose to feed them to nestlings when the abundance of those foods is high and preferred arthropod foods are scarce (Sauter et al. 2006), which are the conditions observed in suburbs (Shawkey et al. 2004). Partly as a result of these inadequate nestling foods, suburban nestlings tend to fledge at significantly lighter masses than do wildland nestlings (Bowman 1998). After fledging and the period of peak growth, juvenile jays increasingly rely on plant foods in their diets, either because rapidly digestible food becomes less necessary as their growth rate slows (Woolfenden 1978) or because digestive efficiency increases with age (Batal and Parsons 2002) and they are better able to digest foods that require longer gut retention times. Most feather growth occurs after nestlings have fledged, and during this time, human-provided foods may be used to fuel feather development (Woolfenden 1978) and influence variation in structural plumage colors. Thus, human-provided foods may negatively affect body condition at fledging, but positively affect ultra-violet (UV)-plumage patterns developed post-fledging.

\section{Study sites}

We compared a wildland population of scrub-jays at Archbold Biological Station to a suburban population at the Placid Lakes Estates subdivision, $10 \mathrm{~km}$ away. Archbold Biological Station is a privately owned preserve where scrub habitat is managed using prescribed fire (for a complete description see Woolfenden and Fitzpatrick 1984). At Archbold, the study tracts for Florida Scrub-Jay are divided into northern and southern units, with the northern portion reserved for demographic study and the southern portion used for experimental studies. For the purposes of this study, "wildland locals" refers to individuals that hatched and remain in the northern tract, and "wildland emigrants" refers to those that hatched in the southern tract but dispersed to the northern tract.

Placid Lake Estates is a suburban housing division comprising homes embedded in a matrix of fragmented and overgrown scrub habitat (for a complete description see Bowman and Woolfenden 2001). At this suburban site, arthropod abundance is lower (Shawkey et al. 2004), nestlings grow more slowly and fledge at lighter masses (Sauter 2005), nest survival is lower (Niederhauser and Bowman 2014), and brood reduction and post-fledging mortality are higher (Bowman 1998, Shawkey et al. 2004) than at the wildland site.

The demography of the wildland population has been studied since 1969 and that of the suburban population since 1991. As part of these long-term studies, all scrub-jays are individually marked with a unique combination of colored bands, all nests within the study areas are located and monitored, and morphometrics are measured for all individuals $11 \mathrm{~d}$ post-hatch and again as nutritionally independent juveniles ( $~ 85 \mathrm{~d}$ posthatch), at which time the outermost right rectrix is also collected. We used data from the 2008 and 2009 cohorts, giving us a sample 
of 68 Florida Scrub-Jay individuals ( 43 from the wildlands and 25 from the suburbs). We chose these years because they are the only years for which we observed dominance behavior at both sites.

\section{Spectroscopy and ptilochronology}

To measure plumage reflectance, we used an Ocean Optics USB-4000 spectrometer (Ocean Optics, Dunedin, Florida, USA) connected to a DH-2000 deuterium halogen light source by a bifurcated fiber optic probe. We averaged measurements from three $3.14 \mathrm{~mm}^{2}$ circles on each feather sample to produce a single reflectance curve for each feather. From this curve, we calculated three color variables: mean brightness, UV chroma, and hue (Montgomerie 2006).

Growth bars are visible light and dark bands on a feather. Each pair of dark and light bands represents $24 \mathrm{~h}$ of feather growth (Grubb 1989). Like tree rings, these growth bars can be used to measure growth rates. Wider growth bars indicate faster feather growth. To measure growth bar width, we used the method described by Grubb (1989). We taped each rectrix to an index card and then used an insect pin to puncture the card at the proximate and distal ends of the feather and the growth bars. Then we removed the feather from the card and used digital calipers to measure the length of the feather as marked by the pinholes. We then measured the 10 growth bars centered on the point two-thirds the length of the feather from the proximate end, and divided this number by 10 to calculate the average growth bar width (Grubb 1989).

\section{Behavioral observations}

To determine patterns of within-brood dominance in both habitats, we observed same-aged siblings interacting at a feeder placed on their natal territories (Woolfenden and Fitzpatrick 1977, Tringali and Bowman 2012). Prior to beginning our observations, we trained individuals to retrieve peanut bits from a gravity feeder with a small opening that allowed only one bird to access peanuts at a time. Once all juveniles on a territory would reliably use the feeder, we began recording observations using a digital camcorder mounted on a tripod. Observations ended when the juveniles ceased to return to the feeder after caching. Video recordings were reviewed in the laboratory, and all interactions and the identities of the individuals involved were recorded. For each antagonistic interaction, the aggressor was assigned a "win" and the receiver a "loss" (Tringali and Bowman 2012). Groups were observed until a linear hierarchy could be determined.

\section{Territory acquisition and reproductive success}

We used historical records of nesting at Archbold Biological Station to compare acquisition of breeding position and reproductive success between suburban and wildland emigrants. Because we cannot be sure if unbanded immigrants are arriving from suburban or wildland sites, we considered only banded individuals dispersing from either the suburban site or from the southern tract of Archbold Biological Station to be immigrants to the northern tract. In total, we identified 50 immigrants to the northern tract, of which 39 were from the southern tract, and 11 from Placid Lake Estates.

\section{Statistical analysis}

To compare the morphometrics, color variables, and condition between juveniles in wildland and suburban habitats, we used ANOVA with habitat, year, and their interaction included in the models. With the exception of hue, the residuals for all models were normally distributed. Transformations did not normalize the distributions for the residuals of hue, so we used untransformed values for all analyses. We used residuals from the regression of mass on tarsus measured at day $11\left(\mathrm{R}^{2}\right.$ adj. $=0.71, P$ $<0.0001, N=68$ ) as an index of nestling body condition. For juvenile condition, we first used principal components analysis to collapse head breadth, head length, tarsus length, and wing chord measured at independence $(N=68)$ into two principal components. Component one was positively correlated most strongly with head length (0.92), head breadth (0.86), tarsus $(0.73)$, and wing chord $(0.60)$, and explained $62.1 \%$ (eigenvalue $=$ 2.48 ) of the variation in skeletal size. Component two also was correlated strongly with wing chord (0.76) and tarsus $(-0.47)$, and explained $20.1 \%$ (eigenvalue $=0.80$ ) of the variation in skeletal size. We then used multiple regression to express mass as a function of skeletal size $\left(\mathrm{R}^{2}{ }_{\text {adj }}=0.56, P<0.0001, N=56\right)$.

We used ANCOVA to determine if plumage color was related to body condition or growth bar width and if these relationships differed between habitats and years. Initially, we ran these models as full factorials, but no three-way interactions were significant, so we present only main effects and the interaction between habitat and condition. We completed these analyses using JMP 7 (SAS Institite, Cary, North Carolina, USA). We calculated effect sizes, $\eta_{\mathrm{p}}{ }^{2}$, and their confidence intervals using the MBESS package (Kelley 2007, Kelley and Lai 2012) in R (R Core Development Team 2008). Because our hypotheses about habitat effects were one-sided, $90 \%$ confidence intervals were calculated to maintain $\alpha$ of 0.05 (Steiger 2004).

We used binomial tests to determine if dominant individuals were more likely than expected by chance to be ranked first for any of the three color variables. Sibling groups were broken into dyads, and each member of the dyad was ranked for the color variables and dominance. If the most dominant bird was also ranked first for the color variable, the dyad was counted as a success. Using a probability of 0.5 , we calculated the binomial Z-ratios for suburban and wildland birds separately using $\mathrm{R}$.

The hypothesis that the UV-shifted plumage of suburban birds represents a mismatch between signaled and actual quality predicts that they should be successful at acquiring breeding territories when immigrating to wildland habitats, but relatively unsuccessful at producing breeding offspring. We compared successful acquisition of breeder status between the migrants from the southern tract and suburban populations using a likelihood ratio test with one degree of freedom. We then created a metric of realized reproductive success relative to reproductive effort. First, we calculated yearly averages for numbers of hatchlings and breeders produced, and standardized these values using Z-scores. We subtracted the standardized number of hatchlings (reproductive effort) from the standardized number of breeders (reproductive success) to create a metric of realized reproductive success relative to effort. We chose this metric because lifetime reproductive success does not control for effort, and we expected that scrub-jays that perceived their mates to be 
Table 1. Morphometric and condition differences between a suburban and a wildland population of Florida Scrub-Jay juveniles.

\begin{tabular}{|c|c|c|c|c|c|c|c|}
\hline Variable & Term & Df & MS & $F$-ratio & $P$ & $\begin{array}{c}\text { Effect size } \\
\left(\eta_{n}{ }^{2}\right)\end{array}$ & $90 \% \mathrm{CI}$ \\
\hline \multirow{5}{*}{$\begin{array}{l}\text { Nestling } \\
\text { mass }\end{array}$} & Habitat & 1 & 38.35 & 0.88 & 0.35 & 0.01 & $0.00-0.09$ \\
\hline & Year & 1 & 49.3 & 1.14 & 0.29 & 0.02 & $0.00-0.10$ \\
\hline & Habitat $\times$ Year & 1 & 12.29 & 0.28 & 0.6 & 0 & $0.00-0.06$ \\
\hline & Error & 64 & 43.4 & & & & \\
\hline & Total & 67 & & & & & \\
\hline \multirow{5}{*}{$\begin{array}{l}\text { Juvenile } \\
\text { mass }\end{array}$} & Habitat & 1 & 0.48 & 0.02 & 0.88 & 0 & $0.00-0.02$ \\
\hline & Year & 1 & 44.17 & 2.22 & 0.14 & 0.03 & $0.00-0.13$ \\
\hline & Habitat $\times$ Year & 1 & 25.66 & 1.29 & 0.26 & 0.02 & $0.00-0.10$ \\
\hline & Error & 64 & 19.89 & & & & \\
\hline & Total & 67 & & & & & \\
\hline \multirow[t]{5}{*}{ Tail length } & Habitat & 1 & 73.57 & 3.28 & 0.08 & 0.05 & $0.00-0.15$ \\
\hline & Year & 1 & 9.81 & 0.44 & 0.51 & 0.01 & $0.00-0.07$ \\
\hline & Habitat $\times$ Year & 1 & 11.86 & 0.53 & 0.47 & 0.01 & $0.00-0.08$ \\
\hline & Error & 64 & 22.45 & & & & \\
\hline & Total & 67 & & & & & \\
\hline \multirow[t]{5}{*}{ Growth bar } & Habitat & 1 & 0.002 & 0.02 & 0.89 & 0 & $0.00-0.03$ \\
\hline & Year & 1 & 0.02 & 0.29 & 0.59 & 0 & $0.00-0.07$ \\
\hline & Habitat $\times$ Year & 1 & 0.11 & 1.25 & 0.27 & 0.02 & $0.00-0.11$ \\
\hline & Error & 59 & 0.08 & & & & \\
\hline & Total & 62 & & & & & \\
\hline \multirow{5}{*}{$\begin{array}{l}\text { Nestling } \\
\text { condition }\end{array}$} & Habitat & 1 & 12.46 & 1.02 & 0.32 & 0.02 & $0.00-0.09$ \\
\hline & Year & 1 & 5.43 & 0.44 & 0.51 & 0.01 & $0.00-0.07$ \\
\hline & Habitat $\times$ Year & 1 & 5.24 & 0.43 & 0.51 & 0.01 & $0.00-0.07$ \\
\hline & Error & 64 & 12.2 & & & & \\
\hline & Total & 67 & & & & & \\
\hline \multirow{4}{*}{$\begin{array}{l}\text { Juvenile } \\
\text { condition }\end{array}$} & Habitat & 1 & $4.03 \times 10^{-4}$ & 1.24 & 0.27 & 0.02 & $0.00-0.12$ \\
\hline & Year & 1 & $3.94 \times 10^{-4}$ & 1.21 & 0.28 & 0.02 & $0.00-0.12$ \\
\hline & Error & 53 & $3.25 \times 10^{-4}$ & & & & \\
\hline & Total & 55 & & & & & \\
\hline
\end{tabular}

of high quality would show more reproductive effort. To determine if this metric differed significantly among individuals breeding locally, dispersing from the suburbs, or dispersing from the wildlands, we used Monte Carlo permutations with 1000 iterations (one-tailed, $\alpha=0.05$ ).

\section{RESULTS}

No differences were detected in either nestling or juvenile mass or body condition or in juvenile tail length between suburban and wildland individuals (Table 1). Mean brightness, UV chroma, and hue differed significantly by year and by habitat, but their interaction was not significant (Table 2). Suburban birds had lower mean brightness, higher UV chroma, and lower hue, indicating more UV-shifted color (Fig. 1). Year had a stronger effect than habitat on plumage color (Table 2). Growth bar width did not differ with habitat or year (Table 1).

Neither nestling nor juvenile condition in either study tract was significantly related to any measure of feather color. Mean brightness, UV chroma, and hue were not significantly dependent on nestling or juvenile condition (Table 2). However, when juvenile condition was used in these models, the habitat and year differences only remained significant for UV chroma and hue. Habitat and year were significant in all models using nestling condition. Growth bar width was not related to any component of color (Table 3).

In the wildlands, dominant juveniles were more likely to have higher mean brightness than subordinates (one-tailed binomial test: $N=25, P=0.02$ ), but this was not true in the suburbs (onetailed binomial test: $N=14, P=0.97)$. However, we did not detect an association between either UV chroma or hue and dominance in either the suburbs (one-tailed binomial tests: $N=15, P=0.5$; $N=12, P=0.81$, respectively) or wildlands (one-tailed binomial tests: $N=24, P=0.97 ; N=24, P=0.15$, respectively).

Of the 50 immigrants to the northern tract of Archbold Biological Station, 28 of the $39(72 \%)$ from the southern tract and 10 of the $11(91 \%)$ from the suburban site bred. We were unable to detect significant differences between immigrants from the suburbs and wildlands at acquiring breeder status ( $\mathrm{Z}$-value $1.3, P=0.1$ ). Immigrants from both the suburban site and wildland southern tract scored lower on the metric of reproductive success relative to effort than did birds that were born and bred within the northern demography tract (Fig. 2). Return on reproductive investment was significantly lower for suburban immigrants relative to wildland immigrants $(P=0.03)$ and wildlands birds breeding locally $(P=0.004)$, but the difference was not significant between wildland immigrants and wildland locals $(P=0.10)$. 
Table 2. Relationships between color variables, habitat, and body condition of nestling and juvenile Florida Scrub-Jay individuals from a suburban and a wildland site.

\begin{tabular}{|c|c|c|c|c|c|c|c|}
\hline Response & Term & Df & MS & $F$-ratio & $P^{\dagger}$ & $\begin{array}{c}\text { Effect size } \\
\left(\eta_{n}^{2}\right)\end{array}$ & $90 \% \mathrm{CI}$ \\
\hline Mean & Habitat & 1 & 4.22 & 5.55 & 0.02 & 0.08 & $0.01-0.19$ \\
\hline \multirow[t]{5}{*}{ brightness } & Nestling condition & 1 & 0.09 & 0.11 & 0.74 & 0 & $0.00-0.05$ \\
\hline & $\begin{array}{l}\text { Habitat } \times \text { Nestling } \\
\text { condition }\end{array}$ & 1 & 0.55 & 0.72 & 0.4 & 0.01 & $0.00-0.08$ \\
\hline & Year & 1 & 26.96 & 35.49 & $<0.0001$ & 0.36 & $0.20-0.47$ \\
\hline & Error & 63 & 0.76 & & & & \\
\hline & Total & 67 & & & & & \\
\hline \multirow[t]{6}{*}{ UV chroma } & Habitat & 1 & 0.0008 & 14.56 & 0.0003 & 0.19 & $0.06-0.31$ \\
\hline & Nestling condition & 1 & $4.00 \times 10^{-6}$ & 0.06 & 0.8 & 0 & $0.00-0.04$ \\
\hline & $\begin{array}{l}\text { Habitat } \times \text { Nestling } \\
\text { condition }\end{array}$ & 1 & $3.40 \times 10^{-6}$ & 0.06 & 0.81 & 0 & $0.00-0.04$ \\
\hline & Year & 1 & 0.002 & 32.25 & $<0.0001$ & 0.34 & $0.18-0.45$ \\
\hline & Error & 63 & $5.70 \times 10^{-5}$ & & & & \\
\hline & Total & 67 & & & & & \\
\hline \multirow[t]{6}{*}{ Hue } & Habitat & 1 & 5781.09 & 5.71 & 0.02 & 0.08 & $0.01-0.20$ \\
\hline & Nestling condition & 1 & 6.82 & 0.01 & 0.93 & 0 & $0-0.008$ \\
\hline & $\begin{array}{l}\text { Habitat } \times \text { Nestling } \\
\text { condition }\end{array}$ & 1 & 12.94 & 0.01 & 0.91 & 0 & $0-0.014$ \\
\hline & Year & 1 & 7324.39 & 7.23 & 0.009 & 0.1 & $0.01-0.22$ \\
\hline & Error & 62 & 1012.99 & & & & \\
\hline & Total & 66 & & & & & \\
\hline Mean & Habitat & 1 & $1.90 \times 10^{-4}$ & 0.0002 & 0.99 & 0 & N/A \\
\hline \multirow[t]{5}{*}{ brightness } & Juvenile condition & 1 & $7.76 \times 10^{-5}$ & 0.0001 & 0.99 & 0 & N/A \\
\hline & $\begin{array}{l}\text { Habitat } \times \text { Juvenile } \\
\text { condition }\end{array}$ & 1 & 0.008 & 0.01 & 0.92 & 0 & $0.00-0.02$ \\
\hline & Year & 1 & 2.87 & 3.76 & 0.06 & 0.07 & $0.00-0.19$ \\
\hline & Error & 51 & 0.76 & & & & \\
\hline & Total & 55 & & & & & \\
\hline \multirow[t]{6}{*}{ UV chroma } & Habitat & 1 & $3.15 \times 10^{-4}$ & 5.02 & 0.03 & 0.09 & $0.01-0.22$ \\
\hline & Juvenile condition & 1 & $9.72 \times 10^{-5}$ & 1.55 & 0.22 & 0.03 & $0.00-0.13$ \\
\hline & $\begin{array}{l}\text { Habitat } \times \text { Juvenile } \\
\text { condition }\end{array}$ & 1 & $3.37 \times 10^{-6}$ & 0.05 & 0.82 & 0 & $0.00-0.04$ \\
\hline & Year & 1 & $7.00 \times 10^{-4}$ & 11.6 & 0.001 & 0.19 & $0.05-0.32$ \\
\hline & Error & 51 & $6.30 \times 10^{-5}$ & & & & \\
\hline & Total & 55 & & & & & \\
\hline \multirow[t]{6}{*}{ Hue } & Habitat & 1 & 7119 & 6.63 & 0.01 & 0.12 & $0.01-0.25$ \\
\hline & Juvenile condition & 1 & 1537.58 & 1.43 & 0.24 & 0.03 & $0.00-0.13$ \\
\hline & $\begin{array}{l}\text { Habitat } \times \text { Juvenile } \\
\text { condition }\end{array}$ & 1 & 798.49 & 0.74 & 0.39 & 0.01 & $0.00-0.10$ \\
\hline & Year & 1 & 9477.26 & 8.83 & 0.005 & 0.15 & $0.03-0.28$ \\
\hline & Error & 50 & 1073.89 & & & & \\
\hline & Total & 54 & & & & & \\
\hline
\end{tabular}

${ }^{\dagger}$ Boldface font indicates statistically significant values.

\section{DISCUSSION}

We predicted that the lack of nestling-appropriate food (arthropods) in the suburbs, combined with the availability of high-fat, high-protein food (peanuts; Fleischer et al. 2003) during feather growth would create a mismatch between body and plumage condition in suburban juveniles, as evidenced by a weaker relationship between body condition and plumage coloration. Contrary to our predictions, suburban birds surviving to nutritional independence did not differ from their wildland counterparts in any morphometric measures. However, although similar in size, suburban juveniles had less bright and more UVshifted plumage compared to wildland juveniles. Although this pattern could suggest a breakdown in condition-dependent signaling, plumage coloration was not related to condition in either habitat.

We also hypothesized that if a mismatch between actual and signaled quality, or dishonest signaling, was occurring, suburban 
Fig. 1. Mean and SE of mean brightness, UV chroma, and hue for suburban (gray) and wildland (green) Florida Scrub-Jay juveniles.
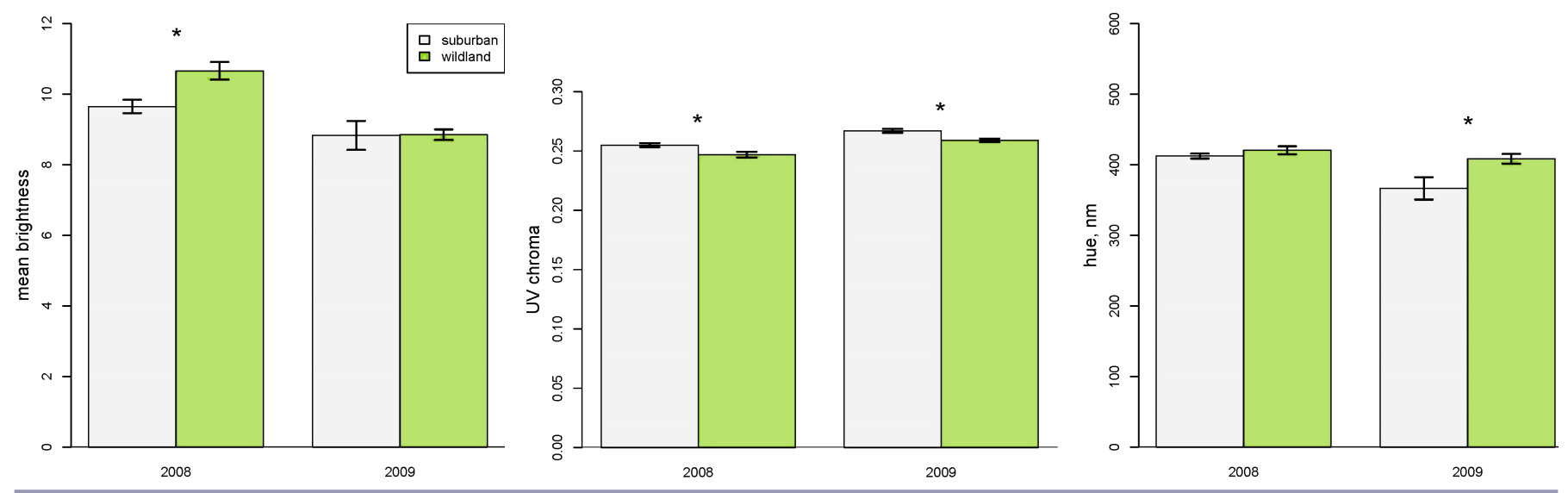

Fig. 2. Mean and SE of realized reproductive success relative to effort for suburban immigrant, wildland immigrant, and wildland local Florida Scrub-Jay individuals. Different letters indicate groups are significantly different from one another.

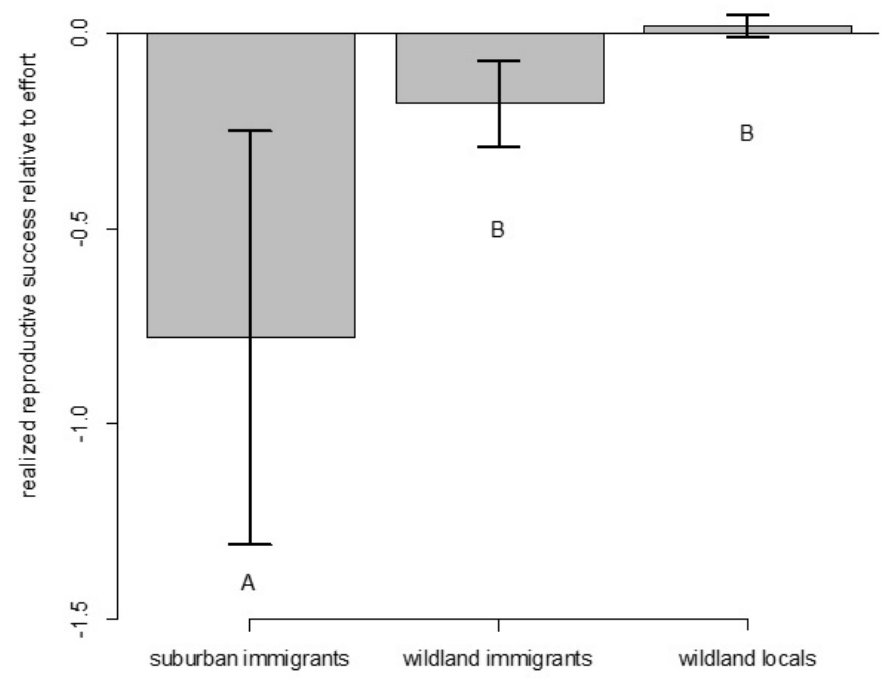

birds dispersing to the wildlands would be more successful at obtaining breeding positions, but less successful at producing offspring compared to those dispersing from wildland sites. Although immigrants from suburban and wildland areas did not differ in their ability to acquire breeder status, immigrants from the suburban site produced fewer breeders relative to their reproductive effort compared to wildland immigrants, partially supporting the hypothesis that plumage reflectance of suburban birds is a dishonest signal.

The morphometrics of nestling and juvenile Florida Scrub-Jay did not differ between the suburban and wildland sites we studied; however, previous research found differences in nestling mass between these sites (Shawkey et al. 2004), and these differences do occur. Our study analyzed data only from individuals surviving to nutritional independence, when we were able to collect a fullygrown rectrix. This analysis obscured size differences that occur between suburban and wildland nestlings because it only included juveniles surviving to independence. When we included data from all nestlings measured $11 \mathrm{~d}$ post-hatch, those from the wildlands averaged $42.5 \mathrm{~g}( \pm 0.51 \mathrm{SE})$ and those from the suburbs $27.0 \mathrm{~g}$ ( $\pm 0.29 \mathrm{SE})$. The smallest suburban nestlings do not survive to nutritional independence, and the suburban site has higher postfledging mortality (Bowman 1998).

Despite the similarities between habitats in body mass and condition of birds surviving to nutritional independence, we detected significant differences in all three measures of color. Suburban juveniles had lower mean brightness, higher UV chroma, and shorter wavelength hue, indicating less brightness, but more UV-shifted feather reflectance. Despite these differences in color, we saw no difference in feather growth between suburban and wildland juveniles, which suggests that suburban birds may be able to produce feathers that reflect more short-wavelength light (higher UV chroma and lower hue) with the same amount of investment in feather growth. No relationship existed between growth bar width and feather color, which supports this conclusion. As juveniles approach nutritional independence, plant foods such as peanuts become more suitable. At the suburban site, the ability to exploit a new and essentially unlimited food high in both fat and protein at the time of increased feather growth may explain how these birds produce more UV-shifted feather color than birds in wildlands.

Neither the nestling nor juvenile condition indices were significant predictors for any of the three color measurements, indicating that color is not related to condition in the wildlands or the suburbs (but see Siefferman et al. 2008). Although condition dependence is a frequently invoked mechanism by which honest signaling is maintained, experimental evidence for this phenomenon is sparse. Evidence for the condition dependence of structural plumage color is mixed, and Peters et al. (2011) suggest that variation in UVcoloration may be related to stress rather than condition. Suburban scrub-jay adults have lower baseline corticosterone than wildland scrub-jays (Schoech et al. 2007), and the young may follow a similar pattern. Nestling corticosterone levels are influenced by maternal provisioning and nest attendance (Rensel et al. 2010). Presumably because of the predictability of human-provided foods, suburban females are able to reduce the time spent away from the nest and increase the time brooding (Niederhauser and Bowman 2014), 
Table 3. Relationships between color and growth bar width of Florida Scrub-Jay juveniles from a suburban and a wildland site.

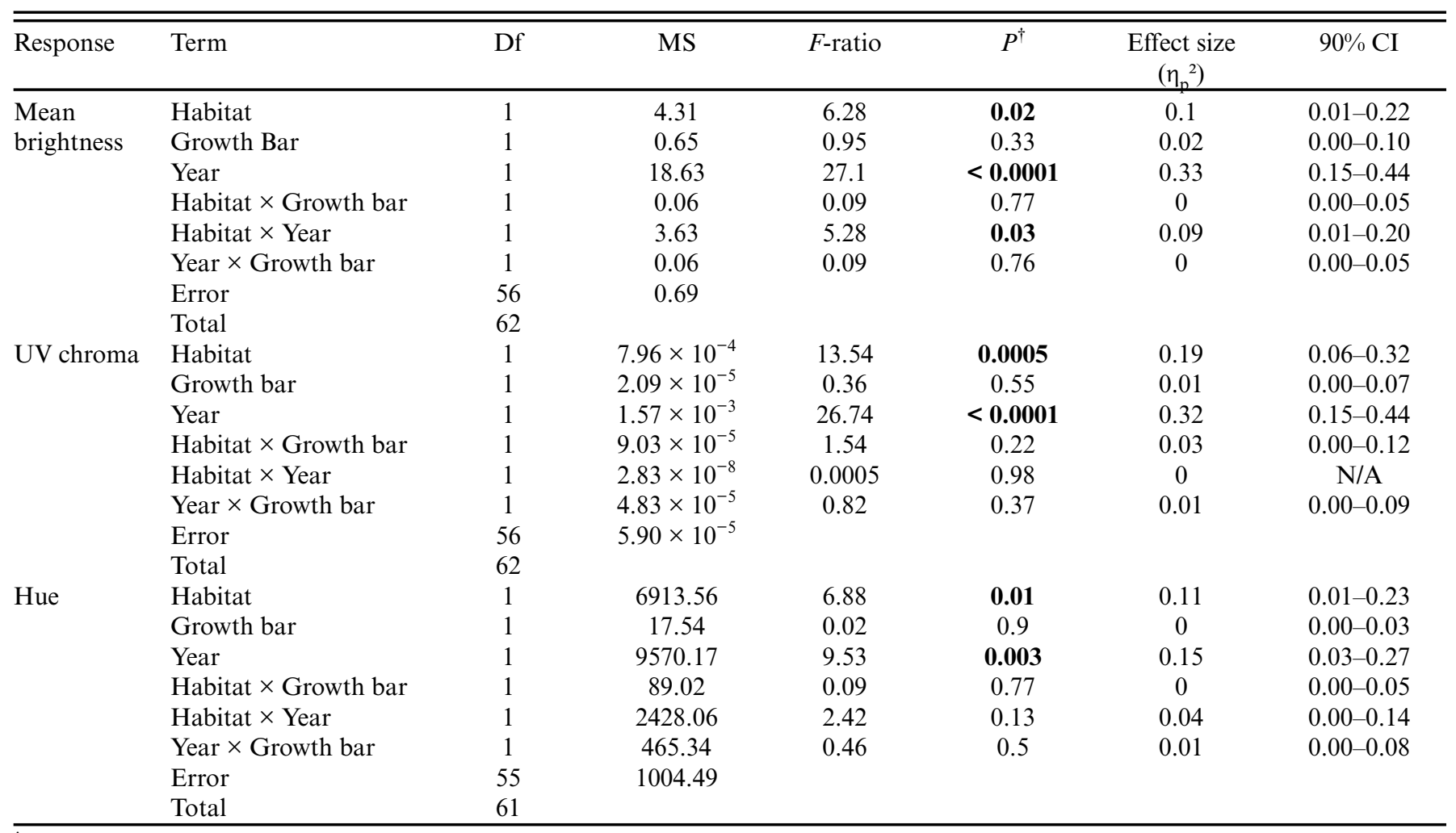

${ }^{\dagger}$ Boldface font indicates statistically significant values.

which may reduce nestling stress. Differences in baseline corticosterone may explain why suburban scrub-jays produce more UV-shifted plumage.

Alternatively, birds in the suburban population may, on average, have more UV-shifted plumage than wildland birds because the selection pressures (increased brood reduction and post-fledging mortality) in the suburbs are stronger. During this study, only $36.6 \%$ of hatched eggs produced fledglings in the suburbs, compared to $63.3 \%$ in the wildlands. This mortality may be nonrandom, with individuals with duller or less UV-shifted plumage more likely to perish then those with brighter or more UV-shifted plumage. If such a difference exists, it may be explained by preferential provisioning from adults. In Eastern Bluebird (Sialia sialis), parents preferentially feed brighter offspring (Ligon and Hill 2010), which would result in duller nestlings being more likely to starve and less likely to survive to independence. Because mortality is so much higher in the suburbs, it may create strong selection pressure for more brightly colored or UV-shifted plumage.

We found that dominant birds were more likely to have higher mean brightness than subordinates at the wildland site, but not at the suburban site. No relationship was detected between dominance and UV chroma or hue in either habitat. It is critical to note that the associations between dominance and color are not consistent across studies. Data collected at Archbold Biological Station from 2008-2011 show that dominant birds are no more likely to have higher mean brightness, UV chroma, or lower hue than expected by chance (Tringali and Bowman 2012). However, using data only from 2008-2010, the result is different: dominant birds are significantly more likely to have higher UV chroma than are subordinates $(P=0.01$, probability of success $=0.75, N=24)$. These inconsistencies make interpreting the differences in binomial test results between suburban and wildland habitats difficult. However, in wildland juveniles, an experimental treatment that reduced UV chroma and increased hue caused a reduction in dominance, which indicates that the UV component of plumage color is used in dominance signaling (Tringali and Bowman 2012). Although the importance of mean brightness in status signaling is unclear, the experimental evidence that the UV component signals dominance among wildland juveniles is unequivocal (Tringali and Bowman 2012). Experimental manipulations in the suburbs proved impossible because too few territories produced more than one young, limiting our ability to replicate experimental treatments.

If suburban birds display a dishonest signal or there is a mismatch between signaled and actual quality, suburban birds would be more likely to acquire breeding positions but have relatively low reproductive success. Contrary to this prediction, acquisition of breeder status did not differ between suburban and wildland immigrants. However, the power to detect differences in acquiring breeder status was extremely low (0.36). Ten of the eleven birds (91\%) dispersing from Placid Lake Estates bred, compared with twenty-eight of thirty-nine ( $72 \%)$ from the south tract, and we think these differences are biologically significant. Additionally, immigrants from the suburban site exhibited lower reproductive success relative to effort than did wildland immigrants, suggesting that suburban immigrants are of lower quality than those from wildlands. 
A mismatch between signaled and actual quality may have important demographic consequences for this Federally Threatened species, and we think this pattern warrants further investigation. Because suburban immigrants score lower on our metric of reproductive success, wildland natives breeding with suburban immigrants likely suffer a fitness cost. This fitness cost represents an anthropogenic effect spilling over to intact habitat and may be indicative of an evolutionary trap whereby wildland natives prefer to pair with suburban immigrants because their perceived quality is high, although their actual reproductive potential is low. Understanding the fitness cost of this evolutionary trap is of increasing importance as suburban birds emigrate or are translocated to managed natural areas. Accurately quantifying the long-term effect of suburban immigration on the demography and population viability of wildlands will be critical to the conservation management of Florida Scrub-Jay.

The numerous environmental changes induced by urbanization may have widespread effects on the reliability of signaling. Urbanization weakens the relationship between body condition and plumage color in Northern Cardinal and eliminates the relationships between body size, song length, and speed (Narango 2012). More research is needed to determine if the urban effects on signal quality are widespread among different types of signals and across taxa.

Local populations of birds within fragmented, urbanizing landscapes often function as metapopulations (Padilla and Rodewald 2015), with individuals moving among populations. Individuals with dishonest signals that move from urban to natural areas may create evolutionary traps, the consequences of which must be understood to manage populations effectively in protected areas, especially as they become increasingly surrounded by urban development.

Responses to this article can be read online at: http://www.ace-eco.org/issues/responses.php/746

\section{Acknowledgments:}

We thank Joseph Niederhauser and numerous interns for assistance in data collection, Allen Downey for statistical advice, and Roarke Donnelly and two anonymous reviewers for helpful comments on an earlier version of this manuscript. Funding was provided by NSF (grants IBN 0346557, SGER 0855879), Sigma Xi, the American Ornithologists Union, and the Frank M. Chapman memorial fund.

\section{LITERATURE CITED}

Batal, A. B., and C. M. Parsons. 2002. Effects of age on nutrient digestibility in chicks fed different diets. Poultry Science 81:400-407. http://dx.doi.org/10.1093/ps/81.3.400

Bowman, R. 1998. Population dynamics, demography, and contributions to metapopulation dynamics by suburban populations of the Florida scrub-jay, Aphelocoma coerulescens. Nongame Wildlife Program final report. Florida Game and Freshwater Fish Commission, Tallahassee, Florida, USA.

Bowman, R., and G. E. Woolfenden. 2001. Nest success and the timing of nest failure of Florida Scrub-Jays in suburban and wildland habitats. Pages 383-402 in J. M. Marzluff, R. Bowman, and R. Donnelly, editors. Avian ecology and conservation in an urbanizing world. Springer, New York, New York, USA. http://dx. doi.org/10.1007/978-1-4615-1531-9_18

Brown, J. S., and B. P. Kotler. 2004. Hazardous duty pay and the foraging cost of predation. Ecology Letters 7:999-1014. http://dx. doi.org/10.1111/j.1461-0248.2004.00661.x

Chace, J. F., and J. J. Walsh. 2006. Urban effects on native avifauna: a review. Landscape and Urban Planning 74:46-69. http://dx.doi. org/10.1016/j.landurbplan.2004.08.007

Coulon, A., J. W. Fitzpatrick, R. Bowman, and I. J. Lovette. 2012. Mind the gap: genetic distance increases with habitat gap size in Florida scrub jays. Biology Letters 8:582-585. http://dx.doi. org/10.1098/rsbl.2011.1244

Fitzpatrick, J. W., B. Pranty, and B. M. Stith. 1994. Florida Scrub Jay statewide habitat map, 1992-1993. Cooperative Agreement 14-16-0004-91-950. U.S. Fish and Wildlife Service and Archbold Biological Station, Lake Placid, Florida, USA.

Fleischer, A. L. Jr., R. Bowman, and G. E. Woolfenden. 2003. Variation in foraging behavior, diet, and time of breeding of Florida Scrub-Jays in suburban and wildland habitats. Condor 105:515-527. http://dx.doi.org/10.1650/7224

Grafen, A. 1990. Biological signals as handicaps. Journal of Theoretical Biology 144:517-546. http://dx.doi.org/10.1016/ S0022-5193(05)80088-8

Grubb, T. C. 1989. Ptilochronology: feather growth bars as indicators of nutritional status. Auk 106:314-320.

Hailman, J. P., K. J. McGowan, and G. E. Woolfenden. 1994. Role of helpers in the sentinel behaviour of the Florida Scrub Jay (Aphelocoma c. coerulescens). Ethology 97:119-140. http://dx.doi. org/10.1111/j.1439-0310.1994.tb01034.x

Johnstone, R. A. 1995. Sexual selection, honest advertisement and the handicap principle: reviewing the evidence. Biological Reviews 70:1-65. http://dx.doi.org/10.1111/j.1469-185X.1995.tb01439.x

Jones, T. M., A. D. Rodewald, and D. P. Shustack. 2010. Variation in plumage coloration of Northern Cardinals in urbanizing landscapes. Wilson Journal of Ornithology 122:326-333. http://dx. doi.org/10.1676/09-082.1

Kelley, A. K., and K. Lai. 2012. MBESS. R package version 3.3.3. [online] URL: http://CRAN.R-project.org/package=MBESS.

Kelley, K. 2007. Confidence intervals for standardized effect sizes: theory, application, and implementation. Journal of Statistical Software 20(8):1-24. [online] URL: http://www.jstatsoft.org/v20/ i08.

Kodric-Brown, A., and J. H. Brown. 1984. Truth in advertising: the kinds of traits favored by sexual selection. American Naturalist 124:309-323. http://dx.doi.org/10.1086/284275

Ligon, R. A., and G. E. Hill. 2010. Feeding decisions of eastern bluebirds are situationally influenced by fledgling plumage color. Behavioral Ecology 21:456-464. http://dx.doi.org/10.1093/beheco/ $\operatorname{arq002}$

Montgomerie, R. 2006. Analyzing colors. Pages 90-147 in G. E. Hill and K. J. McGraw, editors. Bird coloration, volume 1: mechanisms 
and measurements. Harvard University Press, Cambridge, Massachusetts, USA.

Narango, D. L. 2012. Causes and consequences of urbanassociated song variation: a study of vocal behavior in the Northern Cardinal (Cardinalis cardinalis). Thesis. Ohio State University, Columbus, Ohio, USA.

Niederhauser, J. M., and R. Bowman. 2014. Testing sources of variation in nestling-stage nest success of Florida Scrub-Jays in suburban and wildland habitats. Journal of Field Ornithology 85:180-195. http://dx.doi.org/10.1111/jofo.12059

Padilla, B. J., and A. D. Rodewald. 2015. Avian metapopulation dynamics in a fragmented urbanizing landscape. Urban Ecosystems 18:239-250. http://dx.doi.org/10.1007/s11252-014-0390$\mathrm{z}$

Pasinelli, G., and J. R. Walters. 2002. Social and environmental factors affect natal dispersal and philopatry of male red-cockaded woodpeckers. Ecology 83:2229-2239. http://dx.doi.org/10.1890/0012-9658 (2002)083[2229:SAEFAN]2.0.CO;2

Peters, A., R. H. J. M. Kurvers, M. L. Roberts, and K. Delhey. 2011. No evidence for general condition-dependence of structural plumage colour in blue tits: an experiment. Journal of Evolutionary Biology 24:976-987. http://dx.doi.org/10.1111/ j.1420-9101.2011.02229.x

R Core Development Team. 2008. R: a language and environment for statistical computing. R Foundation for Statistical Computing, Vienna, Austria.

Rensel, M. A., T. E. Wilcoxen, and S. J. Schoech. 2010. The influence of nest attendance and provisioning on nestling stress physiology in the Florida scrub-jay. Hormones and Behavior 57:162-168. http://dx.doi.org/10.1016/j.yhbeh.2009.10.009

Rodewald, A. D., D. P. Shustack, and T. M. Jones. 2011. Dynamic selective environments and evolutionary traps in humandominated landscapes. Ecology 92:1781-1788. http://dx.doi. org/10.1890/11-0022.1

Sauter, A. 2005. Shall we feed suburban Florida Scrub-Jays (Aphelocoma coerulescens)? The importance of human-provided foods on parental food choice, and nestling growth and survival. Dissertation. University of Zurich, Zurich, Switzerland.

Sauter, A., R. Bowman, S. J. Schoech, and G. Pasinelli. 2006. Does optimal foraging theory explain why suburban Florida scrub-jays (Aphelocoma coerulescens) feed their young human-provided food? Behavioral Ecology and Sociobiology 60:465-474. http://dx. doi.org/10.1007/s00265-006-0187-z

Schlaepfer, M. A., M. C. Runge, and P. W. Sherman. 2002. Ecological and evolutionary traps. Trends in Ecology and Evolution 17:474-480. http://dx.doi.org/10.1016/S0169-5347(02) 02580-6

Schoech, S. J., R. Bowman, E. S. Bridge, and R. K. Boughton. 2007. Baseline and acute levels of corticosterone in Florida Scrub-
Jays (Aphelocoma coerulescens): effects of food supplementation, suburban habitat, and year. General and Comparative Endocrinology 154:150-160. http://dx.doi.org/10.1016/j.ygcen.2007.05.027

Shawkey, M. D., R. Bowman, and G. E. Woolfenden. 2004. Why is brood reduction in Florida scrub-jays higher in suburban than in wildland habitats? Canadian Journal of Zoology 82:1427-1435. http://dx.doi.org/10.1139/Z04-123

Siefferman, L., M. D. Shawkey, R. Bowman, and G. E. Woolfenden. 2008. Juvenile coloration of Florida Scrub-Jays (Aphelocoma coerulescens) is sexually dichromatic and correlated with condition. Journal of Ornithology 149:357-363. http://dx.doi. org/10.1007/s10336-008-0289-7

Stallcup, J. A., and G. E. Woolfenden. 1978. Family status and contributions to breeding by Florida scrub jays. Animal Behaviour 26:1144-1156. http://dx.doi.org/10.1016/0003-3472(78)90104-5

Steiger, J. H. 2004. Beyond the F test: effect size confidence intervals and tests of close fit in the analysis of variance and contrast analysis. Psychological Methods 9:164-182. http://dx.doi. org/10.1037/1082-989X.9.2.164

Tringali, A., and R. Bowman. 2012. Plumage reflectance signals dominance in Florida scrub-jay, Aphelocoma coerulescens, juveniles. Animal Behaviour 84:1517-1522. http://dx.doi. org/10.1016/j.anbehav.2012.09.025

United Nations. 2012. World urbanization prospects: the 2011 revision. United Nations Department of Economic and Social Affairs, New York, New York, USA. [online] URL: http://www. un.org/en/development/desa/publications/world-urbanization-prospectsthe-2011-revision.html.

Van Dyck, H. 2012. Changing organisms in rapidly changing anthropogenic landscapes: the significance of the 'Umwelt'concept and functional habitat for animal conservation. Evolutionary Applications 5:144-153. http://dx.doi.org/10.1111/ j.1752-4571.2011.00230.x

Wong, M. Y. L. 2012. Abiotic stressors and the conservation of social species. Biological Conservation 155:77-84. http://dx.doi. org/10.1016/j.biocon.2012.05.018

Woolfenden, G. E. 1978. Growth and survival of young Florida Scrub Jays. Wilson Bulletin 90(1):1-18. [online] URL: https://sora. unm.edu/sites/default/files/journals/wilson/v090n01/p0001-p0018. pdf.

Woolfenden, G. E., and J. W. Fitzpatrick. 1977. Dominance in the Florida Scrub Jay. Condor 79:1-12. http://dx.doi.org/10.2307/1367524

Woolfenden, G. E., and J. W. Fitzpatrick. 1984. The Florida Scrub Jay: demography of a cooperative-breeding bird. Princeton University Press, Princeton, New Jersey, USA.

Zahavi, A. 1975. Mate selection-a selection for a handicap. Journal of Theoretical Biology 53:205-214. http://dx.doi. org/10.1016/0022-5193(75)90111-3

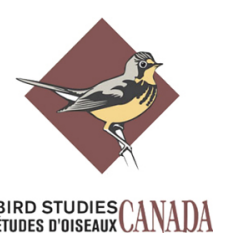

